\title{
Identification of Territorial Industrial Clusters of Russian Economy in View of Their Involvment into the Development of the State Innovation Policy
}

\author{
Elena I. Dorokhova, Vladimir M. Moskovkin, Elena N. Kamishanchenko, Astgik E. Akopyan, \\ Larisa V. Solovyeva, Natalia A. Saprikina, Yuliya L. Rastopchina
}

\begin{abstract}
The article is devoted to the important role of clusters in the innovative development of the economy. The article reviews the particularities and regulatory support of the modern clustering policy of the Russian Federation. The results of the activities of 25 pilot innovative territorial cluster-leaders of the Russian Federation in terms of investment potential in 2012-2018 were estimated in the article. The original method of identification of the innovative territorial clusters was suggested in the article, its main advantages being universalism, comprehensiveness and credibility. Using this methodology, the authors of the article identified the territorial industrial clusters and ranged them according to their innovation potential.
\end{abstract}

Keywords : Cluster, cluster policy, innovation cluster, identification of clusters, innovation territorial cluster, location quotient (LQ), size and focus of clusters.

\section{INTRODUCTION}

Over many years, the world experience of the innovative activities was unbreakably connected to the cluster's activities. "Silicon Valley", "Route 128", "Medicon Valley", "Skolkovo" are privileged to be the symbols of the highest technologies and industrial innovations of the world economy long back. Traditional ways of doing business in a tough competition lose their effectiveness.

In this situation, some unions with the high concentration of the business, sciences and state representatives with the connectedness and cooperation in the core are becoming the industrial growth clusters (the innovation clusters) that gain the scientific and practical experience exchange and making sure of the productive industrial growth and default's

Revised Manuscript Received on July 22, 2019.

* Correspondence Author

Elena I. Dorokhova, Belgorod State National Research University, 85 Pobedy St., Belgorod 308015 Russian Federation

Vladimir M. Moskovkin, Belgorod State National Research University, 85 Pobedy St., Belgorod 308015 Russian Federation

Elena N. Kamishanchenko, Belgorod State National Research University, 85 Pobedy St., Belgorod 308015 Russian Federation

Astgik E. Akopyan, Belgorod State National Research University, 85 Pobedy St., Belgorod 308015 Russian Federation

Larisa V. Solovyeva, Belgorod State National Research University, 85 Pobedy St., Belgorod 308015 Russian Federation.

Natalia A. Saprikina, Belgorod State National Research University, 85 Pobedy St., Belgorod 308015 Russian Federation.

Yuliya L. Rastopchina, Belgorod State National Research University, 85 Pobedy St., Belgorod 308015 Russian Federation. reducing. All the above is progressively increasing of the ineffectiveness of abilities of the region or the state of its geolocation.

In the Russian Federation the innovative developments problem has got two aspects: inner aspect that tightly connects with the main variations of the regions by the levels of the innovative and economic development and outer aspect that clearly emerges that despite of the fact of the highest innovating potential our country is just running behind in the international rating in the comparison with the massive world economical states. In this regard, the necessity of the building up of drastically new national innovative system is growing. In our opinion the structural changings could be provided by the clusterization of the innovative activities.

The importance of the creation of the innovative territorial regions in the Russian Federation has been undermined and emphasized on the all federal level as a hugest part of the Strategy of the innovative developments of Russian in the forthcoming period up to 2020. "Innovative Russia" (Strategiya innovacionnogo razvitiya Rossijskoj Federacii, 2011). The most important directions of the region's clusters development have been dedicated and clearly definite as well as quantity of the 25-pilot regional innovation clusters with diversity of the segment specification in the different regions of Russian. The innovation clusters have got of vitally importance during the period from 2014 due to the anti-Russian economic sanctions.

Innovation clusters became particularly important in the period from 2014 because the clusters had the potential for the development of industry and high technologies, which dominate in Russian imports. In 2016, based on five years of cluster activity experience, by order of the Ministry of Economic Development, 11 leaders in terms of investment attractiveness were singled out among the functioning ones; a road map was developed for them, which reflected promising development indicators by 2020 (Razvitie innovacionnyh klasterov - liderov investicionnoj privlekatel'nosti mirovogo urovnya, 2016).

However it is goes without saying that the foundation of the innovation clusters it's not just an outcome of the command political decision but also it's the reassured result of the 
analytical investigation. It is necessary to commitment the identification of the potential innovative territorial clusters on the territory of Russia and to make the comparable analysis them with those clusters that had been already functioning.

\section{THE THEORETICAL REVIEW}

The so-called definitions as "collaboration", "coworking", and "synergy" are often getting to be the top topics and clue subjects of the scientific reports, forums and the scientific investigations. It clearly emerges the profound comprehension of the formidable role of the over segments connectiveness in the development of the innovative activities.

The usage of the clusters approaches in the innovative politics had been established by the scientist M.Porter who is particularly famous for its model of "competitive diamond ". understanding of the core and the contents of a cluster on the base of the similarity. M. Porter believed that the cluster is a system formed by the merger and interaction of 4 main elements: the company's strategy, structure and competition; supporting industries (Porter, 1998).

According to the Methodology of the European Cluster Observatory, which made a significant contribution to the development of the theory of clustering of economic activity, the cluster is the territorial concentration of the economic activity of interconnected industries. It includes companies of various legal forms and types, producers of goods and service providers, manufacturers of both intermediate and final goods, and services, as well as other innovative actors, such as: research and educational institutions, specialized government agencies, financial subjects and many other institutions that provide related services (Cluster Mapping Tool, 2018).

The theoretical and practical contribution in the conception of the innovation clusters and the methodological aspects of their identification had been made by the scientists as A. Marshall (1982), P. Krugman (2006), X. Temouri (2013), A. Hoen (2006), W. Izard (1960).

\section{METHODOLOGY}

To identify innovative territorial clusters of the Russian Federation, we propose the following algorithm (Fig. 1):

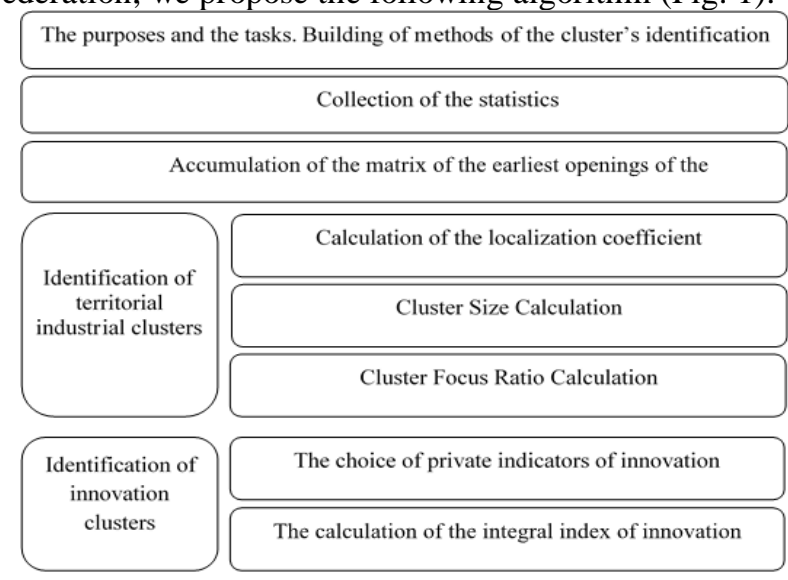

Figure 1. Algorithm of identification of innovative territorial clusters The scientist had made the conclusion of the fully demand conditions; factor conditions and related and

The technique assumes as the first stage of its implementation the collection and systematization of statistical data in the following areas: the total number of the employed population of the Russian Federation; the total number of people employed in a particular branch of the Russian Federation; total employment in the region of the Russian Federation; the number of the employed population in a separate branch of a separate region of the Russian Federation.

The source of statistical data was the Federal State Statistics Service. The analysis was carried out on 82 subjects and on 15 sectors of the economy for the period of 2017. Based on official statistics, with the help of Microsoft Office, a data matrix of $82 \times 15$ is formed, which contains 1,245 absolute indicators:

$$
\left(E_{m p i j}\right)=\left(\begin{array}{cccccc}
E_{11} & E_{12} & \ldots & E_{1 j} & \ldots & E_{1,82} \\
\vdots & \vdots & & \vdots & & \vdots \\
E_{i 1} & E_{i 2} & \ldots & E_{i j} & \ldots & E_{i 82} \\
\vdots & \vdots & & \vdots & & \vdots \\
E_{15,1} & E_{15,2} & \ldots & E_{15 j} & \ldots & E_{15,82}
\end{array}\right),
$$

where: $1 \leq i \leq 15$;

$1 \leq j \leq 82$;

$M$ - number of the objects

$N$ - number of the segments of the economy

The second stage involves the calculation and comparison of three indicators: the coefficient of localization of LQ, cluster size and focus (formulas 2-4). Consequently, the subsequent actions involve the calculation of the above indicators for regions and industries.

The calculation of the coefficient of localization is carried out according to the formula 1 (Izard, 1966).

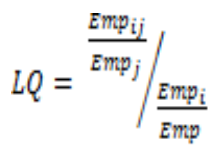

(2)

where: $L Q$ - the coefficient of the localization

$E m p_{i j}-$ the quantity of the occupied population in $\mathrm{i}$ - segment in $\mathrm{j}$ - region;

$E m p_{j}-$ the whole quantity of the occupied

population in $\mathrm{j}$ - region all over the segments;

$E m p_{i}$ - the quantity of the occupied population in $\mathrm{i}$ - segment all the country in general;

Emp - the whole quantity of the occupied population in the whole country.

According to the results of the calculation of the localization coefficient, regions are identified in which the standard value of the LQ $\geq 2$ indicator corresponds to the recommendations of the European Cluster Observatory (Cluster Mapping Tool, 2018). At the third stage, in order to determine the ratio of the number of people employed in each industry in the region to the number of people working in the industry on a national scale, the cluster size indicator is used. 
Size $=\frac{\operatorname{smp}_{\mathrm{ij} j}}{E m p_{\mathrm{i}}}$

The standard value for this indicator is a value equal to $10 \%$ of the total number of private indicators of cluster size, characterized by the highest value (Porter, 1998). At the fourth stage, cluster focus indicators are calculated, which is the ratio of the number of employees in each region to the total number of employees in the region as a whole (formula 4).

$$
\text { Focus }=\frac{E m p_{i j}}{E m p_{j}}
$$

The standard value for this indicator is equal to $10 \%$ of the total number of partial indicators of focus, characterized by the highest value (Porter, 1998).

Based on the obtained intermediate results, a final matrix is formed for all regions and industries, in which we assign one "star" for each indicator meeting the standard (Cluster Mapping Tool, European Cluster Observatory, 2018). Identification of territorial-industry combinations with three "stars" indicates the presence of a natural (potential) cluster.

To study the innovation component of the identified clusters, it is necessary to analyze the innovation statistics on these clusters in the context of economic activities and regions. In order to identify innovation clusters among the identified territorial and sectoral clusters, according to our methodology, seven partial proportional factors, one integral and one reference (table 1), were used.

Table 1: The system of indicators used in the identification of innovative territorial clusters

\begin{tabular}{|c|c|c|}
\hline $\begin{array}{l}\text { Coe } \\
\text { ffici } \\
\text { ent }\end{array}$ & Title & Content \\
\hline $\mathrm{k}_{1}$ & $\begin{array}{l}\text { coefficient of } \\
\text { innovation } \\
\text { activity }\end{array}$ & $\begin{array}{l}\text { the share of innovative } \\
\text { organizations in their total } \\
\text { number, } \%\end{array}$ \\
\hline $\mathrm{k}_{2}$ & $\begin{array}{l}\text { technological } \\
\text { innovation } \\
\text { cost ratio }\end{array}$ & $\begin{array}{l}\text { the share of costs for technological } \\
\text { innovations in the total volume of } \\
\text { goods shipped, work performed, } \\
\text { services, } \%\end{array}$ \\
\hline $\mathrm{k}_{3}$ & $\begin{array}{l}\text { coefficient of } \\
\text { innovative } \\
\text { products }\end{array}$ & $\begin{array}{l}\text { the share of innovative goods, } \\
\text { works, services in the total }\end{array}$ \\
\hline $\mathrm{k}_{4}$ & $\begin{array}{l}\text { coefficient of } \\
\text { technological } \\
\text { innovation }\end{array}$ & $\begin{array}{l}\text { the share of organizations that } \\
\text { carried out technological } \\
\text { innovation in the total number of } \\
\text { organizations, } \%\end{array}$ \\
\hline $\mathrm{k}_{5}$ & $\begin{array}{l}\text { coefficient of } \\
\text { organizationa } \\
1 \text { innovation }\end{array}$ & $\begin{array}{l}\text { the share of organizations that } \\
\text { carried out organizational } \\
\text { innovation in the total number of } \\
\text { organizations, } \%\end{array}$ \\
\hline $\mathrm{k}_{6}$ & $\begin{array}{l}\text { coefficient of } \\
\text { marketing } \\
\text { innovations }\end{array}$ & $\begin{array}{l}\text { the share of organizations that } \\
\text { carried out marketing innovations } \\
\text { in the total number of } \\
\text { organizations, } \%\end{array}$ \\
\hline $\mathrm{k}_{7}$ & coefficient of & the share of organizations that \\
\hline
\end{tabular}

\begin{tabular}{|c|l|l|}
\hline & $\begin{array}{l}\text { environment } \\
\text { al innovation }\end{array}$ & $\begin{array}{l}\text { carried out environmental } \\
\text { innovation in the total number of } \\
\text { organizations,\% }\end{array}$ \\
\hline $\mathrm{K}_{\text {int }}$ & $\begin{array}{l}\text { coefficient of } \\
\text { innovation of } \\
\text { the cluster } \\
\text { (integral) }\end{array}$ & $\begin{array}{l}\text { integral indicator, based on the } \\
\text { calculation of the average } \\
\text { geometric in } \\
\text { coefficients, points }\end{array}$ \\
\hline $\mathrm{G}_{\text {inn }}$ & $\begin{array}{l}\text { indicator of } \\
\text { the use of } \\
\text { advanced } \\
\text { production } \\
\text { technologies }\end{array}$ & $\begin{array}{l}\text { share of advanced production } \\
\text { technologies in the total volume, \% } \\
\text { reference information used for a } \\
\text { comparable assessment of the } \\
\text { integral index of cluster } \\
\text { innovation and the actual amount } \\
\text { of advanced technologies use }\end{array}$ \\
\hline
\end{tabular}

In our opinion, the selected indicators form the optimal system of primary assessment of the innovation potential of the regions. First of all, the indicators take into account the number of organizations in the regions engaged in innovative activities of various types - technological, organizational, marketing and environmental.

Besides, the assessment system also includes an indicator of the share of innovative goods, works and services in the total volume, which allows for a real assessment of the work of innovative organizations in the implementation of domestic innovation projects.

The cost component in the system makes it possible to assess the level of profitability of sales of innovative products together with the already mentioned coefficient of innovative products, works, services $(\mathrm{k} 3)$. It is important here that all partial coefficients are calculated in fractions of units, and therefore there is no need for their further normalization.

The source of statistical information for selecting coefficients characterizing innovation activities of clusters $(\mathrm{k} 1, \mathrm{k} 2, \mathrm{k} 3, \mathrm{k} 4, \mathrm{k} 5, \mathrm{k} 6, \mathrm{k} 7)$ is Federal State Statistics Service of the Russian Federation (section "Science and Innovations") (Nauka, innovacii i informacionnoe obshchestvo, 2018) .

The integral coefficient of cluster innovation for each $\mathrm{i}$ branch $\mathrm{j}$ of the region is represented as the geometric average of the partial coefficients:

$$
\mathrm{K}_{\text {int }}=\sqrt[7]{k_{1} \times k_{2} \times k_{a} \times k_{4} \times k_{5} \times k_{6} \times k_{7}},
$$

In addition, to assess the level of cluster innovation, we developed a five-level, closed-type uniform scale presented in Table 2 .

Table 2: Scale of assessment of the level of innovation of the territorial-industry cluster

\begin{tabular}{|c|l|}
\hline Interval & \multicolumn{1}{|c|}{ Meaning } \\
\hline $0 \leq \mathrm{K}_{\text {int }} \leq 1,75$ & Weak innovation level \\
\hline $1,75<\mathrm{K}_{\text {int }} \leq 3,5$ & average innovation level \\
\hline $3,5<\mathrm{K}_{\text {int }} \leq 5,25$ & high innovation level \\
\hline $5,25<\mathrm{K}_{\text {int }} \leq 7$ & extremely high innovation level \\
\hline
\end{tabular}


At the same time, territorial-industry clusters with a high and very high level of innovation were assigned to the innovation group $\left(\mathrm{K}_{\text {int }}>3,5\right)$.

\section{RESULTS OF THE STUDY}

The above algorithm was applied to the identified territorial industrial clusters. It should be noted that the cluster identification was carried out using the European Cluster Observatory technique (Cluster Mapping Tool, 2018), taking into account the conditions typical for European economies, in which the number of subjects is traditionally significantly lower than Russian, due to the higher concentration of the employed population by industry and regions.

In order to adapt the technique to analyze Russian regions, LQ standard value is reduced to unity $(\mathrm{LQ} \geq 1)$ then re-calculations are made according to the above algorithm (Pavlov et al, 2014). Regions of the Russian Federation identified by applying the method of identification of territorial and sectoral clusters are presented in Table 3.

Table 3: The final table of identification of territorial and sectoral clusters in the regions of the Russian Federation in 2017

\begin{tabular}{|c|c|c|c|c|c|c|c|}
\hline Regions / Activities & 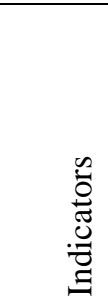 & $\begin{array}{l}\text { Agricultu } \\
\text { re, } \\
\text { forestry, } \\
\text { hunting } \\
\text { and } \\
\text { fishing }\end{array}$ &.$\stackrel{0}{\Xi}$ & 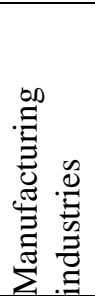 & 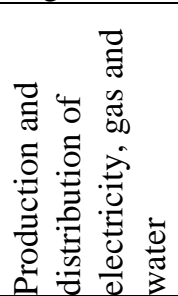 & 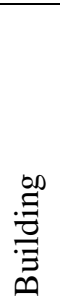 & 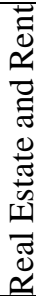 \\
\hline \multirow{3}{*}{ Moscow region } & LQ & & & $*$ & & $*$ & $*$ \\
\hline & Size & & & & $*$ & $*$ & $*$ \\
\hline & Focus & & & $*$ & & & $*$ \\
\hline \multirow{3}{*}{ Moscow } & LQ & & & & & $*$ & $*$ \\
\hline & Size & & & $*$ & $*$ & $*$ & $*$ \\
\hline & Focus & & & $*$ & & & $*$ \\
\hline \multirow{3}{*}{ Saint Petersburg } & LQ & & & & & $*$ & * \\
\hline & Size & & & $*$ & & $*$ & $*$ \\
\hline & Focus & & & $*$ & & & $*$ \\
\hline \multirow{3}{*}{ Volgograd region } & LQ & * & & & $*$ & & \\
\hline & Size & $*$ & & & & & \\
\hline & Focus & $*$ & & $*$ & & & \\
\hline \multirow{3}{*}{ Rostov region } & LQ & * & & & & & \\
\hline & Size & $*$ & & & & $*$ & \\
\hline & Focus & $*$ & & $*$ & & & \\
\hline \multirow{3}{*}{ Republic of Dagestan } & LQ & * & & & & $*$ & \\
\hline & Size & $*$ & & & & & \\
\hline & Focus & $*$ & & & & $*$ & \\
\hline \multirow{3}{*}{ Stavropol region } & LQ & * & & & $*$ & & \\
\hline & Size & $*$ & & & & & \\
\hline & Focus & $*$ & & & & & \\
\hline \multirow{3}{*}{ Republic of Tatarstan } & LQ & $*$ & $*$ & ** & $*$ & $*$ & \\
\hline & Size & $*$ & $*$ & $*$ & $*$ & $*$ & \\
\hline & Focus & & & $*$ & & & \\
\hline \multirow{3}{*}{ Nizhny Novgorod Region } & LQ & & & ** & & $*$ & $*$ \\
\hline & Size & & & $*$ & & & $*$ \\
\hline & Focus & & & $*$ & & & \\
\hline \multirow{3}{*}{ Samara region } & LQ & & & ** & * & & $*$ \\
\hline & Size & & & $*$ & & & $*$ \\
\hline & Focus & & & $*$ & & & \\
\hline \multirow{3}{*}{ Sverdlovsk region } & LQ & & & * & $*$ & & \\
\hline & Size & & $*$ & $*$ & $*$ & & $*$ \\
\hline & Focus & & & & & & \\
\hline \multirow[t]{2}{*}{ Tyumen region } & LQ & & * & & $*$ & * & \\
\hline & Size & & $*$ & & $*$ & $*$ & * \\
\hline
\end{tabular}




\begin{tabular}{|c|c|c|c|c|}
\hline & Focus & $*$ & & $*$ \\
\hline \multirow{3}{*}{ Chelyabinsk region } & LQ & & $*$ & * \\
\hline & Size & & $*$ & \\
\hline & Focus & & $*$ & \\
\hline
\end{tabular}

As a result of the analysis, a final table was formed, which includes the identified innovative territorial clusters of the Russian Federation (Table 4).

Table 4: Calculation of the integral coefficients of innovation clusters $\mathrm{K}_{\mathrm{int}}$ by the identified territorial industrial clusters

\begin{tabular}{|c|c|c|c|c|c|c|c|c|c|c|c|}
\hline No & \begin{tabular}{|l|} 
Region \\
\end{tabular} & \begin{tabular}{|c|} 
Cluster \\
\end{tabular} & $\mathrm{k}_{1}$ & $\mathrm{k}_{2}$ & $\mathrm{k}_{3}$ & $\mathrm{k}_{4}$ & $\mathrm{k}_{5}$ & $\mathrm{k}_{6}$ & $\mathrm{k}_{7}$ & $\mathbf{K}_{\text {int }}$ & $G_{i n n}$ \\
\hline 1 & Moscow region & Real Estate and Rent & 8,5 & 5,6 & 7,1 & 3,1 & 2,3 & 1,6 & 0,6 & $\mathbf{3 , 0}$ & 7 \\
\hline 2 & Moscow & Real Estate and Rent & 16,1 & 4,3 & 14,9 & 4,3 & 2,4 & 1,8 & 2,0 & 4,5 & 8,6 \\
\hline 3 & Saint Petersburg & Real Estate and Rent & 14,8 & 3,1 & 13,8 & 5 & 3,6 & 2,4 & 0,9 & 4,2 & 3,7 \\
\hline 4 & Rostov region & $\begin{array}{l}\text { Agriculture, forestry, } \\
\text { hunting and fishing }\end{array}$ & 8,4 & 3,8 & 7,8 & 1,1 & 1,1 & 1,4 & 4,3 & 2,9 & 1,4 \\
\hline 5 & Volgograd region & $\begin{array}{l}\text { Agriculture, forestry, } \\
\text { hunting and fishing }\end{array}$ & 4,9 & 2,4 & 4,6 & 1,1 & 0,3 & 1 & 1,4 & 1,6 & 1 \\
\hline 6 & Republic of Dagestan & $\begin{array}{l}\text { Agriculture, forestry, } \\
\text { hunting and fishing }\end{array}$ & 2,5 & 0,1 & 1,9 & 0,6 & 0,6 & 1,2 & 0,3 & $\mathbf{0 , 7}$ & 0,3 \\
\hline 7 & Stavropol region & $\begin{array}{l}\text { Agriculture, forestry, } \\
\text { hunting and fishing }\end{array}$ & 4,9 & 2,0 & 4,5 & 0,7 & 0,7 & 0,7 & 0,2 & 1,1 & 0,6 \\
\hline 8 & Republic of Tatarstan & $\begin{array}{l}\text { Manufacturing } \\
\text { industries }\end{array}$ & 21,3 & 2,9 & 20,0 & 4,6 & 4 & 4,7 & 4,8 & 6,5 & 3,2 \\
\hline 9 & $\begin{array}{l}\text { Nizhny Novgorod } \\
\text { Region }\end{array}$ & $\begin{array}{l}\text { Manufacturing } \\
\text { industries }\end{array}$ & 12,8 & 4,0 & 11,3 & 3,7 & 2 & 2,4 & 1,2 & 3,8 & 3,6 \\
\hline 10 & Samara region & $\begin{array}{l}\text { Manufacturing } \\
\text { industries }\end{array}$ & 3,9 & 2,9 & 3,6 & 1,2 & 0,5 & 1,1 & 1,4 & 1,7 & 3,1 \\
\hline 11 & Sverdlovsk region & $\begin{array}{l}\text { Manufacturing } \\
\text { industries }\end{array}$ & 9,4 & 3,1 & 7,8 & 3,1 & 1,6 & 2,3 & 3,0 & 3,6 & 4,4 \\
\hline 12 & Chelyabinsk region & $\begin{array}{l}\text { Manufacturing } \\
\text { industries }\end{array}$ & 7,0 & 2,2 & 6,2 & 3,2 & 1,3 & 2,6 & 0,7 & 2,6 & 3 \\
\hline 13 & Tyumen region & Mining & 12,9 & 1,4 & 6,6 & 3 & 1,7 & 1,5 & 0,2 & 2,1 & 3,7 \\
\hline 14 & Tyumen region & $\begin{array}{l}\text { Electricity, gas and } \\
\text { water }\end{array}$ & 12,9 & 1,4 & 6,6 & 3 & 1,7 & 1,5 & 0,2 & 2,1 & 3,7 \\
\hline 15 & Russian Federation & average & 8,4 & 2,5 & 7,3 & 2,4 & 1,4 & 1,6 & 1,6 & 2,8 & \\
\hline
\end{tabular}

Thus, the two-stage method of identifying innovative territorial clusters revealed 5 territorial innovation clusters. In the first place, according to the scale (Table 2), is the Republic of Tatarstan, the value of the integral coefficient of innovation on which was 6.5. One of the largest Russian clusters, the Kama Innovation Territorial Production Cluster of the Republic of Tatarstan, is successfully operating on the territory of the region, which is a significant factor in Tatarstan's leadership in the implementation of the innovation cluster policy.

In Moscow and St. Petersburg identified clusters of real estate and rentals. From 2012 to 2016, many individual property complexes operated in the regions of Moscow and the region, and in 2016, by order of the Ministry of Economic Development, they were merged into a single Consortium. Today, Moscow and St. Petersburg are the leaders by the number of innovative technologies $(9 \%$ and $4 \%$ of all-Russian innovations, respectively), in terms of the costs of producing innovative goods, works, and services.

The cluster of manufacturing industries of the Nizhny Novgorod region was also included in the group of innovation clusters. It should be noted that in this subject of the Russian Federation an industrial innovation cluster in the field of automotive industry and petrochemistry, created in the framework of the pilot property complex project, functions. But this cluster was not included in the list of leaders of priority property complex from 2016 to 2020. In our opinion, this is due to the fact that the total revenue and return on investment (ROI) were below the level of the leading clusters. Despite this, we believe that the Nizhny Novgorod region is characterized by a high innovative potential, and therefore it is necessary to take measures to strengthen the cluster.

The cluster of processing industries in the Sverdlovsk region is also innovative. The region occupies a leading position in terms of the level of innovative activity, the share of technological innovations, and the share of the production of innovative goods. There is a Titanium cluster in the region.

In the group of clusters with an average level of innovation, we have identified regions that have the potential to develop and intensify innovation. 
Possessing significant agricultural potential, the Rostov Region annually demonstrates high rates of economic growth (Nauka, innovacii i informacionnoe obshchestvo, 2018). In our opinion, a focus on innovation and the creation of an innovative agricultural territorial cluster would be strategically effective measures to ensure stable economic growth within the regional policy of the region. Chelyabinsk region is characterized by an innovative potential for conducting cluster policy in the field of manufacturing. Tyumen region - in the field of mining and production and distribution of energy, gas and water. The Samara region demonstrated an average level of innovation potential, despite the fact that the region has an innovative aerospace cluster, successfully functioning and included in the list of property complex leaders. Volgograd region is also included in the group of regions with an average level of innovative potential.

Members of this group have the potential to develop cluster innovation in the region, but the implementation of this policy requires the fulfillment of a number of conditions: increasing the competitiveness of the regions and, as a result, increasing the investment attractiveness, financing and preferential mechanisms of monetary and fiscal policy in the region, etc.

The territorial industrial clusters of the Republic of Dagestan and the Stavropol Territory were included in the group with a low level of innovation potential, and therefore the formation of clusters in these regions is not recommended at this stage of economic development.

\section{CONCLUSION}

Thus, the application and assessment of the reliability of the developed methodology showed that the innovative territorial clusters identified using the author's methodology are comparable to those functioning in accordance with the Order of the Government of the Russian Federation of August 28, 2012 (Perechen' innovacionnyh territorial'nyh klasterov, 2012) in the territory of the RF subjects. The two-stage method of identifying innovation clusters allows, at the first stage, to identify innovation clusters that meet the criteria of M. Porter, and only then to assess their level of innovation. by region and industry. To adapt the standard values of M. Porter to the Russian economy, their revision is necessary in order to prevent the identification of unreasonably large entities that have nothing to do with clusters.

In the process of cluster identification, a large number of regions, territories and republics were assigned two "stars", which indicates the presence of a cluster formation process in such regions. In the field of agriculture, hunting, forestry, fisheries and fish farming, the following subjects can be distinguished: Tambov Oblast, Republic of Bashkortostan, Mordovia, Altai, Kalmykia, Krasnodar Territory, etc. Many of these regions are agricultural "giants" of Russia, but did not receive three "stars" due to the small concentration of employed workers in the field relative to others in each particular region or due to the small cluster size in the region relative to the country as a whole.

\section{SUMMARY}

Identification of innovation clusters by applying the original method showed that the main clusters in the Russian Federation operate in the manufacturing industry, agriculture, real estate and in the extractive industries, while it should be noted that most of the territorial industrial clusters identified in accordance with the present method correspond to the innovation territorial clusters that officially function on the territory of the country. Two of the fourteen identified clusters belonged to the agricultural sector and were characterized by low innovation rates. That's why they were not identified as innovation territorial clusters.

The main characteristics feature of innovation territorial clusters in the Russian Federation is their territorial proximity to the largest economic centers of the country which causes a significant differentiation of the country's regions in terms of innovative development.

\section{REFERENCES}

1. Cluster Mapping Tool (2018). European Cluster Observatory. Retrieved from:

https://ec.europa.eu/growth/smes/cluster/observatory/cluster-mapping-se rvices/mapping-tool_en

2. Hoen, A. (2000). Three variations on identifying clusters, Netherlands Bureau for Economic Policy Analysis. Retrieved from: http://www.oecd.org/sti/inno/2099308.pdf

3. Isard, W. (1960). Methods of Regional Analysis: an Introduction to Regional Science. Cambridge: Massachusetts: the M.I.T. Press

4. Kasenov, R.R. (2013). Model' nacional'noj innovacionnoj sistemy [The model of the national innovative system], Vestnik ChelGU [Chelyabinsk State University Bulletin], 32: 323, 52-56 [in Russian]

5. Krugman, P. (2011). The new economic geography, now middle-aged. Regional Studies, 45:1, 1-7

6. Markov, L.S. \& Yagol'nicer, M.A. (2006). Ekonomicheskie klastery: identifikaciya i ocenka effektivnosti deyatel'nosti [Economic clusters: identification and estimation of their effectiveness]. Novosibirsk: Institut ekonomiki i organizacii promyshlennogo proizvodstva Sibirskogo otdeleniya Rossijskoj akademii nauk [Institute of Economics and Industrial Engineering, Siberian Branch of the Russian Academy of Sciences] [in Russian]

7. Marshall, A. (1982). Principles of Economics: An introductory volume. London: Palgrave Macmillan UK

8. Nauka, innovacii i informacionnoe obshchestvo (2018) [Science, innovations and informative society]: Federal'naja sluzhba gosudarstvennoj statistiki [Federal State Statistics Service]. Retrieved from:

http://www.gks.ru/wps/wcm/connect/rosstat_main/rosstat/ru/statistics/sc ience_and_innovations/[in Russian]

9. Pavlov, K.V., Rastvorceva, S.N. \& Cherepovskaya, N.A. (2014) Teoretiko-metodicheskie osnovi identifikacii potencial'nyh klasterov v regional'noj ekonomike [Theoretical and methodic basics of identification of the potential clusters in regional economy]. Ekonomichnyj visnyk Donbasu [Economic Herald of the Donbass], 3: 37, 33-42 [in Russian]

10. Perechen' innovacionnyh territorial'nyh klasterov (2012) [List of innovative territorial clusters]: approved by the Order No DM-P8-5060 of August 28, 2012, issued by the Government of the Russian Federation. Retrieved

from: http://economy.gov.ru/wps/wcm/connect/8b69c0004ca1 ebe280f1ab12a c4184fa/perechen_innovacionnih_klasterov.pdf?MOD=AJPERES

11. Porter, M.E. (1998). Clusters and the new economics of competition. Harvard Business Review, 76: 6, 77-90.

12. Razvitie innovacionnyh klasterov - liderov investicionnoj privlekatel'nosti mirovogo urovnya (2016) [Promoting Development of Innovation Clusters -Global Leaders in Attracting Investment]: approved by the Decree No 400 of June 27, 2016, issued by the Ministry of Economic Development of the Russian Federation. Retrieved from: https://cluster.hse.ru/mirror/pubs/share/213074518 [in Russian] 
13. Rynok truda, zanyatost' i zarabotnaya plata (2018) [Labor Market, Employment and Wages]: Federal'naja sluzhba gosudarstvennoj statistiki [Federal State Statistics Service]. Retrieved from: http://www.gks.ru/wps/wcm/connect/rosstat_main/rosstat/ru/statistics/w ages/ [in Russian]

14. Strategiya innovacionnogo razvitiya Rossijskoj Federacii na period do 2020 goda "Innovacionnaya Rossiya - 2020" (2011): [The Strategy of Innovative Development of the Russian Federation until 2020]: approved by the Directive No 2227-r of December 8, 2011, issued by the Government of the Russian Federation. Retrieved from: https://www.garant.ru/products/ipo/prime/doc/70006124/\#72 [in Russian]

15. Temouri, Y. (2012). The Cluster Scoreboard: Measuring the Performance of Local Business Clusters in the Knowledge Economy, OECD Local Economic and Employment Development (LEED) Working Papers, 2012/2013, OECD Publishing. Retrieved from: http://www.oecd.org/leed-forum/publications/WP\%20-\%20The\%20Clu ster\%20Scoreboard.pdf 